\title{
Produk Sabun Transparan Berbahan Herbal di Desa Oro-Oro Ombo, Tlekung, Junrejo, Batu Malang, Provinsi Jawa Timur
}

\author{
Awik Puji Dyah Nurhayati ${ }^{*}$, Elshinta Riantica ${ }^{2}$, Noor Nailis Saa'dah' ${ }^{3}$, Edwin \\ Setiawan ${ }^{4}$, Nova Maulidina Ashari ${ }^{5}$, Adik Mayang Indiani ${ }^{6}$, Agus Wahyudi ${ }^{7}$, Ratna \\ Rintaningrum ${ }^{8}$ dan Ni Wayan ${ }^{9}$
}

1,2,3,4,5,6Departemen Biologi, Fakultas Sains dan Analitika Data (FSAD), Institut Teknologi Sepuluh Nopember (ITS), Indonesia, 60111.

'Departemen Kimia, Fakultas Sains dan Analitika Data (FSAD), Institut Teknologi Sepuluh Nopember (ITS), Indonesia, 60111.

8,9 Departemen Studi Pembangunan, Fakultas Desain Kreatif dan Bisnis Manajemen (FDKBD), Institut Teknologi Sepuluh Nopember (ITS), Indonesia, 60111.

E-mail: awiknurhayati@gmail.com

DOI: https://doi.org/10.37339/jurpikat.v1i2.317

\section{Info Artikel:}

Diterima :

2020-10-15

Diperbaiki :

2020-10-27

Disetujui :

2020-10-28

Kata kunci: Inovasi,

Teknologi, Herbal
Abstrak: Pengolahan empon empon di Desa Oro-oro Ombo-Tlekung-Junrejo-Batu Malang, Provinsi Jawa Timur masih sederhana, yaitu hanya dijual dalam kondisi segar atau produk jamu tradisional, belum dilakukan pengembangan teknologi menjadi produk herbal yang bernilai ekonomi tinggi. Solusi yang diajukan dalam kegiatan pengabdian ini adalah inovasi teknologi pembuatan sabun herbal transparan dari jahe merah, lidah buaya dan bunga melati. Metode pembuatan dilakukan dengan teknik saponifikasi. Hasil uji organoleptik dan efektivitas menunjukkan bahwa formulasi sabun yang paling baik adalah total bahan herbal sebanyak 1,5 g yang tersusun oleh $0,5 \mathrm{~g}$ ekstrak cair bunga melati; $0,4 \mathrm{~g}$ bubuk jahe merah; 0,6 g gel lidah buaya. Kesimpulan dari kegiatan ini bahwa formula sabun transparan yang paling baik adalah formula A yaitu formula ekstrak herbal 1,5 g. Selain itu kegiatan ini mendapat dukungan dari pemerintah Kota Batu, apparat desa dan warga di Desa Oro Oro Ombo. 
Keywords: Innovation, Technology, Herbal
Abstract: The processing of empon empon in the Village of Oro-oro Ombo-Tlekung-Junrejo-Batu Malang, East Java Province is still simple, that is, it is only sold fresh or traditional herbal products, there has not been any technological development to become herbal products with high economic value. The solution proposed in this service activity is the technological innovation of making transparent herbal soap from red ginger, aloe vera and jasmine flowers. The method of manufacture is done by using saponification technique. The organoleptic and effectiveness test results showed that the best soap formulation was a total of $1.5 \mathrm{~g}$ of herbal ingredients composed of $0.5 \mathrm{~g}$ of liquid jasmine flower extract; $0.4 \mathrm{~g}$ powdered red ginger; $0.6 \mathrm{~g}$ of aloe vera gel. The conclusion from this activity is that the best transparent soap formula is formula $A$, namely the herbal extract formula $1.5 \mathrm{~g}$. In addition, this activity received support from the Batu City government, village officials and residents in Oro Oro Ombo Village.

\section{Pendahuluan}

Desa Oro-Oro Ombo merupakan sebuah desa yang berada di wilayah Kecamatan Batu Kota Batu. Sebagian besar kawasan Desa Oro-oro Ombo adalah pertanian, hutan dan datarannya relatif datar dan berbukit terletak di daerah cukup tinggi di bawah kaki gunung Panderman, dan tanah kas desa yang terletak di kaki gunung Panderman ini merupakan asset yang sangat menggiurkan bagi para pelaku bisnis jika masyarakat lokal tidak mampu mengolahnya secara baik dan benar. Desa Oro-Oro Ombo merupakan salah satu kawasan tersertifikasi pertanian organik di Kota Batu. Beberapa hasil pertanian organik yang dihasilkan meliputi padi, kale, sawi, kangkung, jambu kristal, kopi, tomat, terong, lettuce, kentang, paprika dan sladri. Jenis komoditi perkebunan yang cukup potensial dan merupakan tanaman unggulan di antara lain produksi Jahe $9.390 \mathrm{M}^{2}$, Laos $310 \mathrm{M}^{2}$, Kencur $68 \mathrm{M}^{2}$, Kunyit $788 \mathrm{M}^{2}$ dan Temulawak $395 \mathrm{M}^{2}$.

Pengembangan potensi empon empon ini sangat menjanjikan karena memiliki banyak khasiat untuk kesehatan. Hal ini didukung dengan beredar kabar bahwa virus corona bisa ditangkal dengan ramuan jamu, yang terdiri dari ramuan jahe yang disebut mpon-mpon atau empon-empon. Permasalahan dalam kegiatan pengabdian ini adalah bahwa pengolahan empon empon masih sederhana, yaitu hanya dijual dalam kondisi segar ataupun produk jamu. Empon empon hanya 
dimanfaatkan sebagai tambahan produksi pertanian saja, belum dilakukan pengembangan teknologi untuk membuat produk herbal yang bernilai ekonomi tinggi. Beberapa produk jamu belum memenuhi standar sesuai standar karena bahan baku produk jamu. Solusi yang diajukan dalam kegiatan pengabdian ini adalah Pengembangan Teknologi Pengolahan Produk Herbal Ramah Lingkungan di Desa Oro-oro Ombo-Tlekung-Junrejo- Batu Malang, Provinsi Jawa Timur sebagai usaha peningkatan potensi daerah dan peningkatan ekonomi masyarakat setempat melalui peningkatan pengetahuan, keterampilan pembuatan produk herbal yang ramah lingkungan.

Ditengah maraknya pemakaian sabun berbahan kimia pada masa pandemic ini sebagai pencuci tangan dapat menyebabkan iritasi pada kulit. Hal ini ditandai dengan munculnya efek kulit yang kering dan bersisik hingga menyebabkan kulit terbakar dibawah sinar matahari. Sehingga perlu dilakukan inovasi produk sabun herbal yang mengandung senyawa bioaktif alami yang sangat bermanfaat bagi kulit. Hal ini didukung dengan kelimpahan bahan herbal cukup banyak di di Desa Orooro Ombo sehingga dapat digunakan sebagai bahan sabun herbal (Sari dkk., 2017)

\section{Metode}

Lokasi kegiatan Pengabdian kepada Masyarakat Berbasis Produk di Laboratorium Zoologi Departemen Biologi FMIPA ITS dan di Desa Oro-oro OmboTlekung-Junrejo-Batu Malang, Propinsi Jawa Timur. Kegiatan yang dilakukan adalah:

a. Koordinasi dengan pemerintah Kota Batu dan inisiasi pembentukan kerjasama dalam bentuk MoU dengan ITS.

b. Pendataan produk herbal yang potensial yang telah ada di masyarakat

c. Survei lokasi di Desa oro Oro Ombo Kota Batu.

d. Survei lanjutan dengan Dinas Pertanian Pemkot Batu Malang.

e. Benchmarking ke UPT Materia Medica Batu Malang, Propinsi Jawa Timur.

f. Persiapan alat dan bahan pembuatan sabun herbal transparan.

g. Formulasi sabun herbal transparan berdasarkan Widyasanti dkk. (2016).

Formula sabun herbal transparan yang disajikan pada Tabel 1. 
Tabel 1. Formula bahan pembuatan sabun herbal transparan

\begin{tabular}{lccccc}
\hline \multirow{2}{*}{ Bahan } & \multicolumn{5}{c}{ Perlakuan } \\
\cline { 2 - 6 } & $\mathbf{1}$ & $\mathbf{2}$ & $\mathbf{3}$ & $\mathbf{4}$ & $\mathbf{5}$ \\
\hline Minyak kelapa (gr) & 9 & 9 & 9 & 9 & 9 \\
Minyak Zaitun (gr) & 21 & 21 & 21 & 21 & 21 \\
Minyak Jarak (gr) & 30 & 30 & 30 & 30 & 30 \\
As. Stearat (g) & 21 & 21 & 21 & 21 & 21 \\
NaOH 30\% (gr) & 61 & 61 & 61 & 61 & 61 \\
Etanol 96\% (gr) & 45 & 45 & 45 & 45 & 45 \\
Gula pasir (g) & 45 & 45 & 45 & 45 & 45 \\
Akuades (gr) & 25,2 & 23,7 & 22,2 & 20,7 & 19,2 \\
Gliserin (g) & 39 & 39 & 39 & 39 & 39 \\
Essence bunga melati (gr) & 0 & 0,5 & 1,0 & 1,5 & 2,0 \\
Bubuk jahe merah (g) & 0 & 0,4 & 0,8 & 1,2 & 1,6 \\
Gel lidah buaya (g) & 0 & 0,6 & 1,2 & 1,8 & 2,4 \\
\hline
\end{tabular}

(Widyasanti dkk., 2016)

Formulasi pembuatan sabun dilakukan dengan cara, serbuk $\mathrm{NaOH}$ dilarutkan dengan akuades hingga kosentrasi 30\%. Asam lemak berupa minyak kelapa (VCO), minyak zaitun dan minyak jarak dicampurkan dalam panci stainless steel selanjutnya dipanaskan hingga suhu $90^{\circ} \mathrm{C}$. Larutan $\mathrm{NaOH}$ dimasukkan kedalam campuran minyak dan asam stereat. Campuran diaduk hingga homogen dan dipanaskan kembali hingga suhu $90^{\circ} \mathrm{C}$, selanjutnya ditambahkan gula halus secara bertahap. Saat sabun sudah dingin dimasukkan gliserin dan ditambahkan etanol kemudian dihomogenkan hingga terbentuk cairan berwarna transparan. Saat suhu larutan turun hingga $\pm 70^{\circ} \mathrm{C}$ ditambahkan bubuk lidah buaya dan bunga melati dan dicampur hingga sempurna. Pendinginan sabun memerlukan waktu \pm 24 jam.

h. Uji Organoleptik pada Produk Sabun dilakukan terhadap 10 responden pada 24 jam, 7 hari, 14 hari, dan 21 hari setelah sabun dikeluarkan dari cetakan (Sukawaty dkk., 2016). Parameter yang diukur warna, transparansi, tekstur dan aroma.

i. Analisis Data

j. Proses Pengemasan 
Diagram kegiatan pelaksanaan Abdimas disajikan pada Gambar 1.

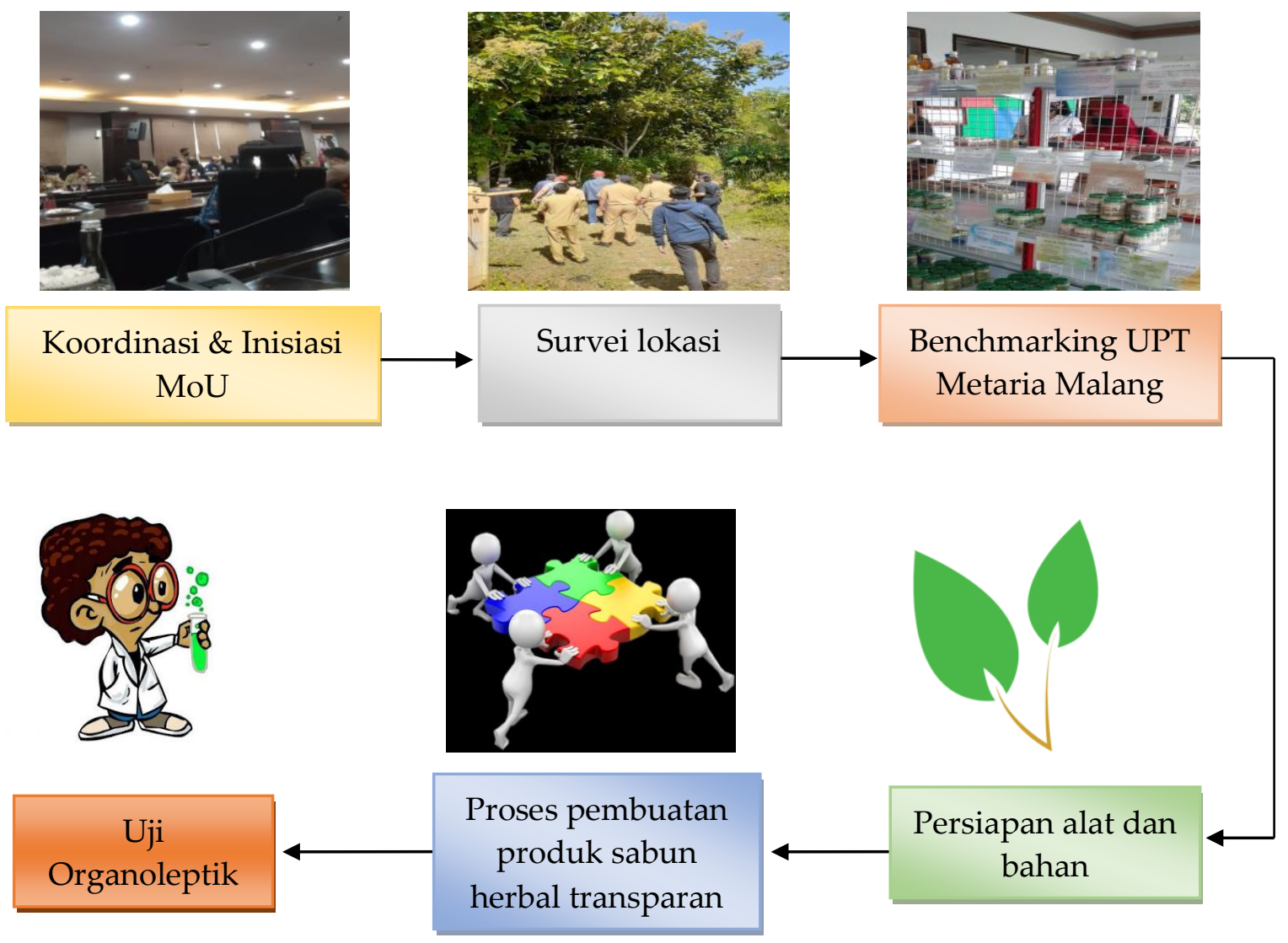

Gambar 1. Diagram kegiatan pelaksanaan Abdimas

\section{Hasil dan Pembahasan}

Sabun herbal yang diproduksi menunjukkan karakteristik. Uji organoleptic terhadap 10 responden dilakukan 4 tahap, yakni 24 jam, 7 hari, 14 hari dan 21 hari (Tabel 2). Warna sabun yang dihasilkan dari setiap formulasi memiliki perbedaan kuning kecokelatan hingga cokelat tua (Gambar 2). Sabun herbal formula A hampir sama dengan formula kontrol, yakni kuning kecokelatan, sedangkan formula B kecokelatan; C dan D cokelat tua. Perbadaan warna ini disebabkan oleh komposisi bahan herbal. Semakin banyak komposisi bahan herbal yang ditambahkan akan menghasilkan warna yang semakin gelap.

Data uji organoleptik sabun herbal oleh 10 responden disajikan pada Tabel 2. 
Tabel 2. Data uji organoleptik sabun herbal oleh 10 responden

\begin{tabular}{|c|c|c|c|c|c|}
\hline \multirow{2}{*}{ Deskripsi Produk } & \multirow{2}{*}{ Formula } & \multicolumn{4}{|c|}{ Waktu pengamatan } \\
\hline & & 24 jam & 7 hari & 14 hari & 21 hari \\
\hline \multirow{5}{*}{ Warna } & K & $\mathrm{KC}$ & $\mathrm{KC}$ & $\mathrm{KC}$ & $\mathrm{KC}$ \\
\hline & A & $\mathrm{KC}$ & $\mathrm{KC}$ & KC & $\mathrm{KC}$ \\
\hline & B & $\mathrm{C}$ & $\mathrm{C}$ & $\mathrm{C}$ & $\mathrm{C}$ \\
\hline & $\mathrm{C}$ & $\mathrm{T}$ & $\mathrm{T}$ & $\mathrm{T}$ & $\mathrm{T}$ \\
\hline & $\mathrm{D}$ & $\mathrm{T}$ & $\mathrm{T}$ & $\mathrm{T}$ & $\mathrm{T}$ \\
\hline \multirow{5}{*}{ Transparansi } & $\mathrm{K}$ & +++ & +++ & +++ & +++ \\
\hline & A & +++ & +++ & +++ & +++ \\
\hline & $\mathrm{B}$ & ++ & ++ & ++ & ++ \\
\hline & C & + & + & + & + \\
\hline & $\mathrm{D}$ & - & - & - & - \\
\hline \multirow{5}{*}{ Tekstur (kekerasan) } & $\mathrm{K}$ & $\mathrm{L}$ & $\mathrm{P}$ & $\mathrm{P}$ & $\mathrm{P}$ \\
\hline & A & $\mathrm{L}$ & $\mathrm{Pa}$ & $\mathrm{P}$ & $\mathrm{P}$ \\
\hline & B & $\mathrm{L}$ & $\mathrm{Pa}$ & $\mathrm{P}$ & $\mathrm{P}$ \\
\hline & C & $\mathrm{L}$ & $\mathrm{Pa}$ & $\mathrm{P}$ & $\mathrm{P}$ \\
\hline & $\mathrm{D}$ & $\mathrm{L}$ & $\mathrm{P}$ & $\mathrm{P}$ & $\mathrm{P}$ \\
\hline \multirow{5}{*}{ Aroma } & $\mathrm{K}$ & $\mathrm{E}$ & $\mathrm{E}$ & $\mathrm{E}$ & $\mathrm{E}$ \\
\hline & A & MM & $\mathrm{MM}$ & M & M \\
\hline & B & $\mathrm{M}$ & $\mathrm{M}$ & M & M \\
\hline & C & M & M & M & M \\
\hline & D & MJ & MJ & MJ & M \\
\hline
\end{tabular}

Keterangan formula :

Formula K (Kontrol); Formula A (Ekstrak herbal 1,5 g) ; Formula B (Ekstrak herbal 3 g) ; Formula C (Ekstrak herbal 4,5 g) ; Formula D (Ekstrak herbal 6 g). KC : Kuning kecokelatan ; C : Cokelat ; T : Cokelat tua ; L : Lunak ; P : Padat ; Pa : Padat (permukaan sedikit berair) ; - : Tidak transparan $;+$ : Cukup transparan ; ++ : Transparan ; +++ : Sangat transparan ; B : Tidak beraroma ; MJ : Beraroma melati dan jahe ; $\mathrm{M}$ : Beraroma melati ; $\mathrm{MM}$ : Beraroma melati sangat kuat.

a. Warna Sabun

Pengaruh yang paling dominan pada warna sabun adalah terletak pada jumlah bubuk jahe yang ditambahkan, karena dari ketiga jenis bahan herbal yang ditambahkan kedalam basis sabun, hanya bubuk jahe yang memiliki warna, sedangkan gel lidah buaya dan ekstrak melati cenderung tidak berwarna. Selain itu, warna sabun juga disebabkan karena kandungan minyak zaitun, minyak jarak dan gula halus. Minyak zaitun yang digunakan memiliki warna kuning cerah (Rowe dkk., 2009) sedangkan minyak jarak memiliki warna kekuningan (Hambali, 2006), adapun minyak kelapa cenderung tidak berwarna atau bening (Zulfadli, 2018). Zat 
warna dari jahe menyebabkan warna kekuningan karena ada kandungan minyak atsiri (Rinanda et al., 2018).

b. Transparansi Sabun

Transparansi produk yang dihasilkan dari produksi sabun herbal transparan memiliki tingkat yang berbeda (Gambar 2). Transparansi paling baik diketahui dari sabun herbal kontrol dan sabun dengan formula A. Formula D cenderung tidak menunjukkan transparansinya atau dapat dianggap pekat. Transparansi yang dihasilkan dari produk sabun herbal ini disebabkan karena penambahan glukosa dari gula halus dan gliserin serta etanol yang ditambahkan pada basis sabun (Sukeksi dkk., 2018), semakin banyak konsentrasi glukosa dan gliserin yang ditambahkan dapat menyebabkan sabun herbal semakin transparan (Sukawaty dkk, 2016). Produk sabun herbal transparan dari formula a,b,c,d dan e disajikan pada Gambar 2.

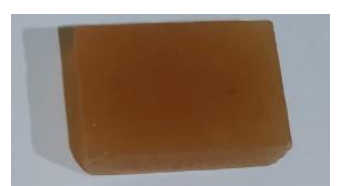

a

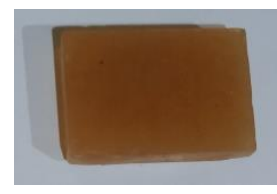

$\mathrm{b}$

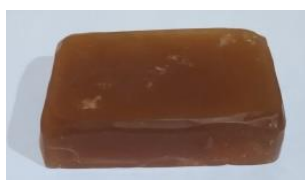

C

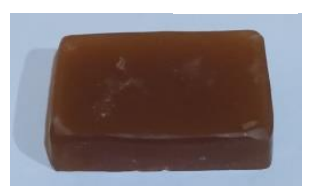

e

Gambar 2. Produk sabun herbal transparan dari formula a,b,c,d dan e.

\section{c. Tekstur Sabun}

Tekstur sabun herbal transparan mengalami perubahan bentuk dari hari pertama sampai ke- 7. Hal ini disebabkan karena proses saponifikasi pada sabun yang belum sempurna (Sukawaty dkk., 2016). Proses penyimpanan atau masa curing pada sabun herbal menyebabkan penguapan pada kadar air didalam sabun. Pada hari ke 7, formula sabun yang bertekstur padat sempurna adalah formula D dan control. Pengamatan hari ke 14 dan 21, seluruh sabun memiliki tekstur yang sama padat. Proses saponifikasi sempurna setelah masa simpan sabun 14 hari.

\section{d. Aroma Sabun}

Aroma sabun yang paling dominan adalah aroma melati. Formula A memiliki aroma melati yang sangat kuat pada 24 jam hingga 7 hari. Aroma melati pada sabun tersebut mulai menguap sehingga pada pengamatan hari ke 14 dan ke 21 aroma melati tidak sekuat pada pengamatan hari pertama dan ke tujuh. Penurunan aroma 
pada sabun ini disebabkan penguapan. Jahe dan melati memiliki kandungan senyawa minyak menguap yang biasa dikenal sebagai minyak atsiri. Senyawa turunan minyak atsiri mampu menghasilkan aroma yang khas untuk setiap bahan herbal (Rinanda et al., 2018 dan Maghfiroh dan Ainy, 2014).

e. Kadar Air Sabun

Kadar air tertinggi pada formula A dan B. Formula C yang memiliki tekstur lebih lunak (Tabel 2). Masa simpan 21 hari menunjukkan formula D memiliki tekstur lebih keras. Tekstur yang lebih lunak tersebut menunjukkan adanya kadar air yang lebih banyak. Kadar air pada sabun ini dapat mempengaruhi masa simpan sabun dan kelarutan sabun. Sabun dengan kadar air sedikit memiliki masa simpan yang lebih lama karena kelarutannya dalam air menjadi lebih sedikit sehingga penggunaannya menjadi lebih efisien (Sukeksi dkk., 2018).

f. Efek Samping Sabun terhadap Kulit

Uji efek samping sabun pada kulit dilakukan di 21 hari terhadap 10 responden (Tabel 3), menunjukkan tidak adanya efek samping, karena sabun herbal transparan tidak mengandung senyawa alkali (Sukeksi dkk., 2018). Sabun herbal transparan mampu membersihkan kotoran dengan baik, tetapi busa yang dihasilkan sedikit. Jumlah busa pada sabun dipengaruhi oleh penambahan asam stearate (Muis, 2015). Data uji efektivitas sabun herbal oleh 10 responden disajikan pada Tabel 3.

Tabel 3. Data uji efektivitas sabun herbal oleh 10 responden

\begin{tabular}{cccc}
\hline Formula & Tingkat kebersihan & Jumlah Busa & Efek samping/iritasi \\
\hline K & +++ & +++ & - \\
A & +++ & +++ & - \\
B & +++ & ++ & - \\
C & +++ & ++ & - \\
D & +++ & ++ & - \\
\hline
\end{tabular}

Keterangan hasil pengamatan :

Tingkat kebersihan : + : Kurang bersih, ++ : Cukup bersih, +++ : Sangat bersih

Jumlah busa : - : Tidak berbusa, + : Kurang, ++ : Cukup, +++ : Banyak

Efek samping/iritasi : - : Tidak ada iritasi, + : Iritasi ringan, ++ : Iritasi parah.

g. Kemasan Produk

Kemasan produk sabun herbal digunakan kertas karton (Gambar 3) dengan pertimbangan harga relative tidak mahal, mudah didapat, diproses dan diproduksi, selain itu mudah didaur ulang (Wardhani, 2014). Kemasan berbentuk pillow box berwarna kemasan sesuai dengan konsep herbal. Bungkus kemasan digunakan plastik wrap atau seal dan ditambahan silica gel untuk menyerap air untuk 
mengurangi kelembaban (Maulida dkk., 2017). Identitas merek 'BIOITSHERBAL dan dilengkapi dengan informasi komposisi, berat bersih, khasiat dan manfaat, tanggal kadaluarsa produk dan kontak produsen (Rambe dan Afifuddin, 2012). Ilustrasi kemasan produk sabun herbal transparan disajikan pada Gambar 3.
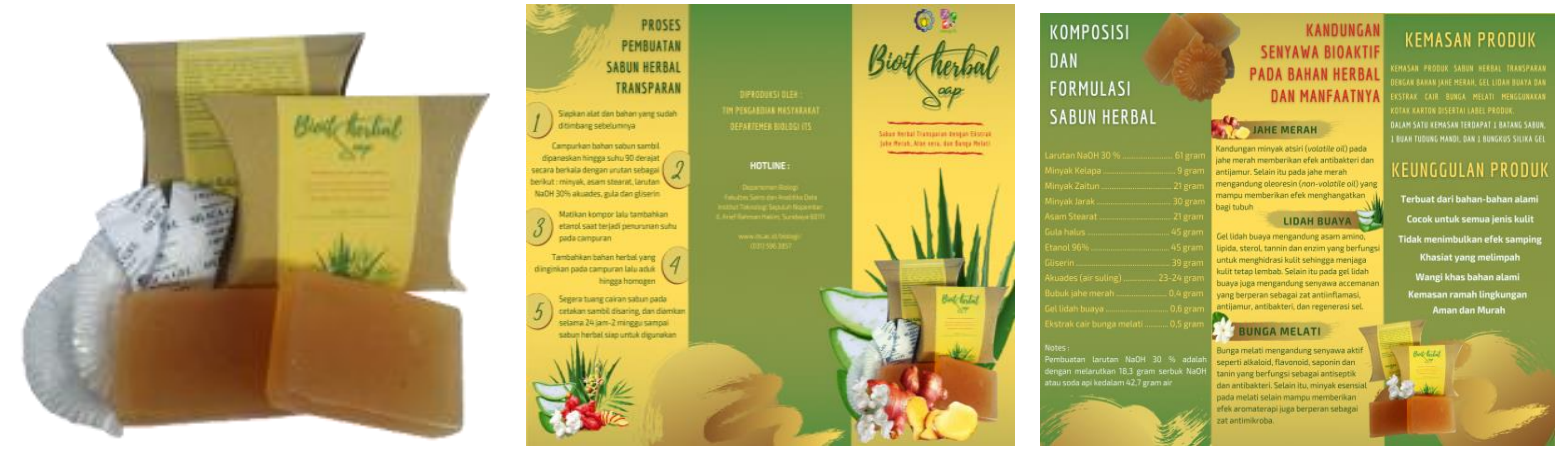

Gambar 3. Ilustrasi kemasan produk sabun herbal transparan

\section{Kesimpulan}

Kesimpulan dari kegiatan Pengabdian masyarakat Berbasis Produk ini antara lain:

1. Formulasi sabun transparan paling baik adalah formula A yaitu formula sabun dengan penambahan ekstrak herbal sebanyak $1,5 \mathrm{~g}$.

2. Kegiatan Pengabdian masyarakat ini mendapat dukungan dari pemerintah Kota Batu, apparat desa dan warga di Desa Oro Oro Ombo.

\section{Ucapan Terima Kasih}

Ucapan terima kasih disampaikan kepada:

1. Pemkot Kotamadya Batu, Malang yang telah mendukung kerjasama Kegiatan Pengabdian Masyarakat sehingga terbentuk MOU anatara Pemkot dengan ITS.

2. UPT Materia Medica Batu Malang, Propinsi Jawa Timur yang telah memberikan ilmu pengetauan mengenai teknologi pengolahan herbal.

3. Penyuluh Kehutan dan AMKE (Area Edukasi Daerah Konservasi ) yang telah menyediakan lahan dan sarana kegiatan KKN dan Pengabdian Masyarakat.

4. Mahasiswa KKN dari Deoartemen Biologi, Teknik Lingkungan, Teknik Industri dan Teknik Kimia yang ikut berperan Kegiatan Pengabdian Masyarakat Berbasis Produk Teknologi Pengolahan Herbal.

5. Kepala Desa, aparat dan warga Oro Ombo Kota Batu yang telah berperan aktif dalam penyediaan lahan untuk teknologi pengolahan herbal 


\section{Referensi}

Hambali, E. 2006. Jarak Pagar Pengganti Biodiesel. Jakarta : Penebar Swadaya.

Hambali, E., Suryani, A., dan Rivai, M. 2005. Membuat Sabun Transparan Untuk Gift Dan Kecantikan. Jakarta : Penebar Plus

Maghfiroh dan Ainy, E.Q. 2014. Uji Aktivitas Antibakteri Ekstrak Bunga Jasminum sambac Ait. terhadap Pertumbuhan Bakteri Staphylococcus aureus ATCC 25923 dan Shigella flexneri ATCC 1202. Seminar Nasional XI Pendidikan Biologi FKIP UNS. 413-418

Maulida, Ginting, M., dan Wici, H. 2017. Ekstraksi Abu Vulkanik Gunung Sinabung Untuk Menghasilkan Silika Gel. Jurnal Teknik Kimia USU. Vol 6(3) : 41-46

Muis, A. 2015. Pengaruh Konsentrasi Natrium Hidroksida, Asam, Stearat, dan Bahan Tambahan Lainnya terhadap Kualitas Sabun Transparan dari Virgin Coconut Oil. Jurnal Penelitian Teknologi Industri. Vol. 7(2) : 81-92

Rambe, Y.M., dan Afifuddin, S. 2012. Pengaruh Pencantuman Label Halal pada Kemasan Mie Instan terhadap Minat Pembelian Masyarakat Muslim. Jurnal Ekonomi dan Keuangan. Vol. 1(1) : 36-45

Rinanda, T., Isnanda, R.P., and Zulfitri. 2018. Chemical Analysis of Red Ginger (Zingiber officinale Roscoe var rubrum) Essential Oil and Its Anti-biofilm Activity against Candida albicans. Natural Product Communications. Vol. 13(12) : 1587-1590

Rowe, R.C., Sheskey, P.J., dan Quin. 2009. Handbook of Pharmaneutical Excipient $6^{\text {th }}$ Edition. London : Pharmaneutical Press and American Pharmacist Association.

Sari, R., Riyanta, A.B., Wibawa, A.S. 2017. Formulasi dan Evaluasi Sabun Padat Antioksidan Ektrak Maserasi Kulit Buah Pisang Kepok (Musa normalis L). Jurnal Para Pemikir. Vol. 6(2) : 151-155

Sukawaty, Y., Warnida, H., dan Artha, A.V. 2016. Formulasi Sediaan Sabun Mandi Padat Ekstrak Etanol Umbi Bawang Tiwai (Eleutherine bulbosa (Mill.) Urb.). Jurnal Media Farmasi. Vol. 13(1) : 14-22.

Sukeksi, L., Sianturi, M., dan Setiawan, L. 2018. Pembuatan Sabun Transparan Berbasis Minyak Kelapa dengan Penambahan Ekstrak Buah Mengkudu (Morinda citrifolia) sebagai Bahan Antioksidan. Jurnal Teknik Kimia USU. Vol. 7(2) : 33-39

Wardhani, P.K. 2014. Potensi Pembuatan Produk Kemasan Ramah Lingkungan Studi Kasus Kota Bandung. Jurnal Universitas Pembangunan Jaya. Vol. 1(1) : 17-24

Zulfadli, T. 2018. Kajian Sistem Pengolahan Minyak Kelapa Murni (Virgin Coconut Oil) dengan Metode Pemanasan. International Journal of Natural Science and Enginering. Vol. 2(1) : 34-41 